\title{
Effect of high-dose fentanyl on renal function in dogs
}

\author{
Departamento de Anestesiologia da Faculdade de Medicina de Botucatu - UNESP - São Paulo, Brazil
}

\begin{abstract}
Our objective was to determine the effects of high-dose fentanyl on canine renal function (RF). We anesthetized with sodium pentobarbital (SP) 16 dogs, randomly divided into 2 groups: in G1, SP was given alone, and in G2, combined with 0.05 mg. $^{-k^{-1}}$ fentanyl. All animals were ventilated artificially and had catheterized left and right femoral veins and left femoral artery for fluid infusion, drug administration, blood collection, and hemodynamic measurement. Urine was collected throughout the experiment. Attributes of RF were studied. SP did not alter RF, which was significantly altered by fentanyl. In G2, slower heart rates, mean arterial pressure, creatinine clearance, urinary output, osmolar clearance and fractional excretion of sodium and potassium were observed. G1 had a behavior attributed to extracellular volume expansion and no RF alterations. In G2, we observed significant decreases in RF due to opioid-induced hemodynamic changes, not discarding the possible action of aldosterone.
\end{abstract}

UNITERMS: High-dose fentanyl. Renal function. Dog.

\section{INTRODUCTION}

$\mathrm{H}$ igh-dose fentanyl anesthesia is often used because this technique is usually associated with a stable cardiovascular hemodynamic course. However, there are few reports on the effects of high-dose fentanyl on renal function (RF) and authors have not obtained similar results, performing their studies on man as well as on dogs. ${ }^{1.4}$ Fentanyl has also been used in combination with other drugs known to alter RF.

The primary aim of this study is to report the renal response of dogs to a high dose of fentanyl. These dogs were compared to a reference group receiving sodium pentobarbital (SP), a drug which does not alter RF. ${ }^{5.6}$

\author{
Anddress for correspondence: \\ Profa. Dra. Yara Marcondes Machado Castiglia \\ Dept ${ }^{2}$ de Anestesiologia da FMB - UNESP \\ Distrito de Rubião Junior - Caixa Postal 530 \\ Botucatu/SP - Brasil - CEP 18618-970
}

\section{MATERIAL AND METHODS}

Anesthesia was induced in 16 healthy male mongrel dogs ( 8 to $20 \mathrm{~kg}$ ) with $30 \mathrm{mg} \cdot \mathrm{kg}^{-1}$ of SP. In the first experimental phase, anesthesia was maintained with SP $\left(5 \mathrm{mg} \cdot \mathrm{kg}^{-1}\right)$. In the second phase, animals were randomly divided into 2 groups of 8 dogs and were differentiated as follows:

Group 1 (G1) - control group, maintenance with SP only, and;

Group 2 (G2) - maintenance with SP and 0.05 mg.kg ' fentanyl.

A cuffed endotracheal tube was inserted, and the animals received pancuronium bromide $\left(0.08 \mathrm{mg} \cdot \mathrm{kg}^{-1}\right.$ in the first dose and $0.03 \mathrm{mg} \cdot \mathrm{kg}^{-1}$ for maintenance). Ventilation was controlled by a K. Takaoka model 660 apparatus with room air and adjusted to maintain normal blood-gas pressures. Left and right femoral veins were catheterized for fluid infusion, drugs administration, blood collection and measurement of inferior vena cava pressure (ICP). Channelization of the left femoral artery was carried out for measurements of mean arterial pressure (MAP) (Hg manometer). Urethral catheterization was performed. 
During the first phase, the animals received Ringer's solution ( $0.4 \mathrm{ml} \cdot \mathrm{kg}^{-1} \cdot \mathrm{min}^{-1}$ - extracellular volume expansion) for $30 \mathrm{~min}$, followed by a prime dose of 30 mg.kg ${ }^{-1}$ creatinine and $4 \mathrm{mg} . \mathrm{kg}^{-1}$ para-aminohipuric acid (PAH). Immediately afterwards, a solution of 0.15 percent creatinine and 0.06 percent $\mathrm{PAH}$ in Ringer $(0.6 \mathrm{mg} . \mathrm{kg}$ ${ }^{1} \cdot \mathrm{min}^{-1}$ creatinine and $0.24 \mathrm{mg} \cdot \mathrm{kg}^{-1} \cdot \mathrm{min}^{-1} \mathrm{PAH}$ ) was administered by continuous drip infusion with a Gilson pump model Hp1, until the end of the experiment. There were 4 clearance periods, each lasting $15 \mathrm{~min}$.

Forty-five min after prime, the first clearance period began with $\mathrm{V}$ measurement (always after emptying the bladder), venous blood collection and determinations of MAP, ICP, and heart rate (HR). After the first clearance period end, the second phase of the experiment started with the second clearance period immediately after fentanyl administration. The third clearance period began immediately after the end of the second, and the fourth started 30 min after the end of the third.

The bladder was emptied and urine always collected at the end of each period. Blood samples were collected in the middle of each period. The mean values of the readings were calculated from those obtained at the beginning and end of each clearance period. The following attributes were recorded:

- Hemodynamics - HR, MAP, ICP, PAH clearance $\left(\mathrm{C}_{\mathrm{PAH}}\right)$, renal blood flow (RBF) and renal vascular resistance (RVR);

- $\quad$ Blood - hematocrit (Ht)and plasma osmolarity $\left(\mathrm{P}_{\text {osm }}\right.$;

- $\quad$ Renal function - creatinine clearance $\left(\mathrm{C}_{\mathrm{cr}}\right)$, filtration fraction (FF), urinary output (V), urinary osmolarity $\left(\mathrm{U}_{\text {osm }}\right)$, osmolar clearance $\left(\mathrm{C}_{\mathrm{osm}}\right)$, free water clearance $\left(\mathrm{C}_{\mathrm{H} 2 \mathrm{O}}\right)$, and fractional excretion of sodium ( $\mathrm{Na}$ ) and potassium $(\mathrm{K})\left(\mathrm{FE}_{\mathrm{Na}}\right.$ and $\left.\mathrm{FE}_{\mathrm{K}}\right)$.

The attributes were studied at the following times:

- $\quad$ 1st phase: M1, control time for each animal obtained $45 \mathrm{~min}$ after prime of creatinine and PAH;

- $\quad$ 2nd phase: M2, immediately after the end of M1; M3, immediately after M2; M4, $30 \mathrm{~min}$ after the end of M3.

In G2, M2, M3 and M4 were obtained immediately, 15 and 60 min after fentanyl administration.

PS and pancuronium maintenance dose was carried out $30 \mathrm{~min}$ before M1 and M4.

All serum and urine samples were later assayed for creatinine and $\mathrm{PAH}$ concentrations using colorimetric techniques. ${ }^{7.8}$ Osmolarity was obtained through cryoscopic lowering. $\mathrm{Na}$ and $\mathrm{K}$ levels were determined using a flame photometer with oxyacetylene.
From this information, the following were derived: clearance $(\mathrm{C})=\mathrm{U} . \mathrm{V} / \mathrm{P}$ where $\mathrm{U}$ and $\mathrm{P}$ are the urine and plasma substance concentration $\left(\mathrm{mg} \cdot \mathrm{ml}^{-1}\right) ; \mathrm{FF}=\mathrm{C}_{\mathrm{cr}} / \mathrm{C}_{\mathrm{PAH}}$; $\mathrm{C}_{\text {osm }}=\mathrm{U}_{\text {osm }} \mathrm{V} / \mathrm{P}_{\text {osm }} ; \mathrm{C}_{\mathrm{H} 2 \mathrm{O}}=\mathrm{V}-\mathrm{C}_{\text {osm }} ; \mathrm{FE}=\mathrm{C} / \mathrm{C}_{\mathrm{cr}} \times 100 ;$ $\mathrm{RBF}=\mathrm{C}_{\mathrm{PAH}} /(1-\mathrm{Ht})$; and RVR = MAP / RBF.

Statistical analysis was carried out using the profile analysis. ${ }^{910}$ For attributes presenting a high coefficient of variation (greater than 40 percent), the transformations were studied according Kempthorne." A value of $\mathrm{p}<$ 0.05 was considered statistically significant. The $\alpha$ prefixed was 0.05 .

\section{RESULTS}

Among the hemodynamics attributes of G1, MAP (Fig. 2) was higher at M4 and $\mathrm{C}_{\mathrm{PAH}}$ was lower at M4. With respect to RF, V (Fig. 4) increased from M2 to M3 and M4. $\mathrm{U}_{\text {osm }}$ (Fig. 5) decreased from $\mathrm{M} 1$ on, $\mathrm{C}_{\mathrm{H} 2 \mathrm{O}}$ (Fig. 7) increased from $\mathrm{M} 1$ on, and $\mathrm{FE}_{\mathrm{Na}}$ and $\mathrm{FE}_{\mathrm{K}}$ (Figs. 8, 9) increased from M2 to M4 (Table 1).

In comparison with the baseline values, HR (Fig. 1) and MAP (Fig. 2) decreased immediately after $0.05 \mathrm{mg} . \mathrm{kg}$ ' of fentanyl (G2). All values of $\mathrm{C}_{\mathrm{cr}}, \mathrm{V}, \mathrm{C}_{\mathrm{osm}}, \mathrm{FE}_{\mathrm{Na}}$ and $\mathrm{FE}_{\mathrm{K}}$ (Figs. 3, 4, 6, 8, 9) decreased after fentanyl. On the other hand, all values of $\mathrm{C}_{\mathrm{H} 2 \mathrm{O}}$ increased from M2 onwards (Table $1)$. There were no consistent changes in any of the remaining attributes over the experimental period.

\section{DISCUSSION}

$\mathrm{SP}$ is a useful agent to induce and maintain anesthesia for experimental research and does not produce significant RF changes. ${ }^{5.6}$ In small- to medium-sized dogs, such as the ones we used, HR is between $60-120$ beats per minute. ${ }^{12}$ In our study, the early observed increase in HR was attributed to a sympathetic ${ }^{13}$ or vagolytic ${ }^{14}$ origin or reflex through the arterial baroreceptor. ${ }^{15}$

The increase in MAP only at M4 was probably due to a superficial anesthesia level. Greater sympathetic activity as well as an increase in RVR (not significant) and a decrease in $\mathrm{C}_{\mathrm{PAH}}$ (is actually indexed to renal plasma flow) may have occurred from M3 to M4. The large extracellular volume expansion performed in order to obtain high urinary output and more reliable results of $\mathrm{C}_{\mathrm{PAH}}$ and $\mathrm{C}_{\mathrm{cr}}$ actually resulted in high V. Examination of the literature shows that the observed hemodynamic changes 
are similar to those reported in dogs by other investigators. They observed decreases in V only $15 \mathrm{~min}$ after the injection of SP into dogs. ${ }^{6.16}$ Lower $\mathrm{U}_{\text {osm }}$ was attributed to increasing values of $\mathrm{V}$, which is not evidence of water diuresis, since $\mathrm{C}_{\mathrm{H} 2 \mathrm{O}}$ increased, yet continued negative, and there was a progressive increase in $\mathrm{C}_{\text {osm }}, \mathrm{FE}_{\mathrm{Na}}$ and $\mathrm{FE}_{\mathrm{K}}$.

Greater venous return and preload due to extracellular volume expansion cause aterial distention with liberation of arterial natriuretic peptide, which has natriuretic and diuretic actions. There is inhibition of vasopressin release by arterial distention and also of renin release by extracellular volume expansion. Thus, with the increase in extracellular volume, as expected there was greater elimination of water, and also of solutes.

The administration of fentanyl to the well-anesthetized dogs of $\mathrm{G} 2$ resulted in rapid decreases in HR and MAP. Because fentanyl has no significant direct peripheral cardiovascular effects, the HR decrease must have been due to a central effect - a reduction of efferent neurogenic and humoral sympathetic tone. It follows that the higher the preexisting sympathetic activity, the greater the possibility for cardiovascular depression from fentanyl. ${ }^{17}$ However, the mechanism involved may be bradycardia caused by fentanyl mediated by vago. ${ }^{18-20}$

Hypertension seems to be dependent on action on sympathetic nerv terminals, ${ }^{21}$ or fentanyl may even lower the plasma levels of techolamines ${ }^{17,22}$
Table 1

Hemodynamic and renal function attributes [mean (SD)] in G1 (control) and G2 (fentanyl).

\begin{tabular}{|c|c|c|c|c|}
\hline & M1 & M2 & M3 & M4 \\
\hline \multicolumn{5}{|c|}{ HR (beats. $\mathrm{min}^{-1}$ ) } \\
\hline Group 1 & $144(18)$ & $145(19)$ & $150(18)$ & $146(23)$ \\
\hline Group 2 & $138(35)$ & $106(24)^{*}$ & $107(25)^{\star}$ & $104(31)^{\star}$ \\
\hline \multicolumn{5}{|c|}{ MAP $(\mathrm{mmHg})$} \\
\hline G1 & $114(2)$ & $113(2)$ & $112(2)$ & $121(2)^{\star}$ \\
\hline G2 & $115(3)$ & $82(2)^{*}$ & $76(2)^{\star}$ & $82(2)^{\star}$ \\
\hline \multicolumn{5}{|c|}{ ICP $\left(\mathrm{cmH}_{2} \mathrm{O}\right)$} \\
\hline G1 & $5.4(2.2)$ & $5.5(2.3)$ & $5.4(2.3)$ & $5.5(2.2)$ \\
\hline G2 & $5.4(2.3)$ & $5.5(1.9)$ & $5.7(2.4)$ & $5.8(2.0)$ \\
\hline \multicolumn{5}{|c|}{$\mathrm{C}_{\mathrm{PAH}}\left(\mathrm{ml} \cdot \mathrm{min}^{-1} \cdot \mathrm{kg}^{-1}\right)$} \\
\hline & $14(7)$ & $14(6)$ & $16(5)$ & $11(6)^{\star}$ \\
\hline G2 & $14(8)$ & $13(6)$ & $13(7)$ & $11(4)$ \\
\hline \multicolumn{5}{|c|}{ RBF $\left(\mathrm{ml} \cdot \mathrm{min}^{-1} \cdot \mathrm{kg}^{-1}\right)$} \\
\hline G1 & $17(11)$ & $19(10)$ & $20(9)$ & $14(8)$ \\
\hline G2 & $20(12)$ & $19(10)$ & $19(11)$ & $15(7)$ \\
\hline \multicolumn{5}{|c|}{ RVR $\left(\mathrm{mmHg} \cdot \mathrm{ml}^{-1} \cdot \mathrm{min}^{-1}\right)$} \\
\hline G1 & $0.41(0.17)$ & $0.39(0.16)$ & $0.35(0.12)$ & $0.51(0.18)$ \\
\hline G2 & $0.44(0.22)$ & $0.35(0.20)$ & $0.36(0.23)$ & $0.38(0.16)$ \\
\hline \multicolumn{5}{|c|}{$\operatorname{Ccr}\left(\mathrm{ml} \cdot \mathrm{min}^{-1} \cdot \mathrm{kg}^{-1}\right)$} \\
\hline G1 & $3.7(1.1)$ & $4.0(1.3)$ & $3.8(1.3)$ & $3.4(1.7)$ \\
\hline G2 & $3.6(1.5)$ & $2.8(1.0)^{\star}$ & $3.2(1.5)^{\star}$ & $2.9(1.4)^{\star}$ \\
\hline \multicolumn{5}{|c|}{ V $\left(\mathrm{ml}^{-} \mathrm{min}^{-1} \cdot \mathrm{kg}^{-1}\right)$} \\
\hline G1 & $0.09(0.06)$ & $0.10(0.06)$ & $0.14(0.08)^{\star}$ & $0.15(0.09)^{\star}$ \\
\hline G2 & $0.13(0.09)$ & $0.11(0.09)^{\star}$ & $0.09(0.08)^{\star}$ & $0.08(0.08)^{*}$ \\
\hline \multicolumn{5}{|c|}{ Uosm (mOsm.kgH $\left.\mathrm{O}_{2} \mathrm{O}^{-1}\right)$} \\
\hline G1 & $711(283)$ & $550(201)^{*}$ & $506(196)^{\star}$ & $466(225)^{*}$ \\
\hline G2 & $578(162)$ & $556(101)$ & $560(125)$ & $526(111)$ \\
\hline \multicolumn{5}{|c|}{$\operatorname{Cosm}\left(\operatorname{ml} \cdot \min ^{-1}\right)$} \\
\hline G1 & $2.8(1.1)$ & $2.6(1.5)$ & $3.2(1.8)^{\star}$ & $3.2(2.0)^{*}$ \\
\hline G2 & $2.5(1.8)$ & $1.5(1.1)^{*}$ & $1.3(1.1)^{\star}$ & $1.3(0.9)^{\star}$ \\
\hline \multicolumn{5}{|c|}{$\mathrm{C}_{\mathrm{H} 2 \mathrm{O}}\left(\mathrm{ml} \cdot \mathrm{min}^{-1}\right)$} \\
\hline & $-1.5(1.4)$ & $-1.0(0.7)^{*}$ & $-1.1(0.7)^{*}$ & $-0.9(0.7)^{\star}$ \\
\hline G2 & $-1.1(0.7)$ & $-0.6(0.5)^{*}$ & $-0.6(0.5)^{\star}$ & $-0.5(0.4)^{\star}$ \\
\hline \multicolumn{5}{|l|}{$\mathrm{FE}_{\mathrm{Na}}(\%)$} \\
\hline & $1.8(1.1)$ & $2.2(1.3)$ & $3.2(1.8)^{*}$ & $3.7(2.4)^{*}$ \\
\hline G2 & $3.3(4.4)$ & $1.9(2.5)^{\star}$ & $1.4(1.8)^{*}$ & $1.8(2.5)^{*}$ \\
\hline \multicolumn{5}{|l|}{$\mathrm{FE}_{\mathrm{K}}(\%)$} \\
\hline G1 & $22.5(16.4)$ & $23.6(13.1)$ & $32.2(17.3)^{*}$ & $42.7(29.6)^{*}$ \\
\hline G2 & $25.4(12.6)$ & $17.6(9.3)^{*}$ & $15.2(7.8)^{\star}$ & $27.6(17.3)$ \\
\hline
\end{tabular}

" $p<0.05$

$\mathrm{HR}=$ heart rate; $\mathrm{MAP}=$ mean arterial pressure; $I C P=$ inferior vena cava pressure; $\mathrm{C}_{\mathrm{PAH}}=\mathrm{PAH}$ clearance $; \mathrm{RBF}=$ renal blood flow; RVR = renal vascular resistance; $\mathrm{C}_{c r}=$ creatinine clearance; $\mathrm{V}=$ urine output; $\mathrm{U}_{\mathrm{osm}}=$ urinary osmolarity; $\mathrm{C}_{\mathrm{osm}}=$ osmolar clearance; $\mathrm{C}_{\mathrm{H} 2 \mathrm{O}}=$ free water clearance; $\mathrm{FE}=$ fractional excretion. $\mathrm{M} 1$ = control moment $(\mathrm{G} 1$ and $\mathrm{G} 2)$; M2 = immediately after fentanyl (G2); M3 = 15 min after fentanyl (G2); M4 = 60 min after fentanyl (G2). 
through a central effect - a reduction in efferent neurogenic tone and humoral sympathetic tone. However, Priano ${ }^{4}$ believes fentanyl liberates catecholamines from the adrenal medulla and peripheral nerves by central mediation, which may explain the increase he observed in the RVR of dogs to which only fentanyl ( 25 and $50 \mu \mathrm{g} . \mathrm{kg}^{-1}$ ) had been administered. Results differing from these may be due to the previous administration of other drugs such as barbiturates, which cause central depression and sympathetic inhibition.

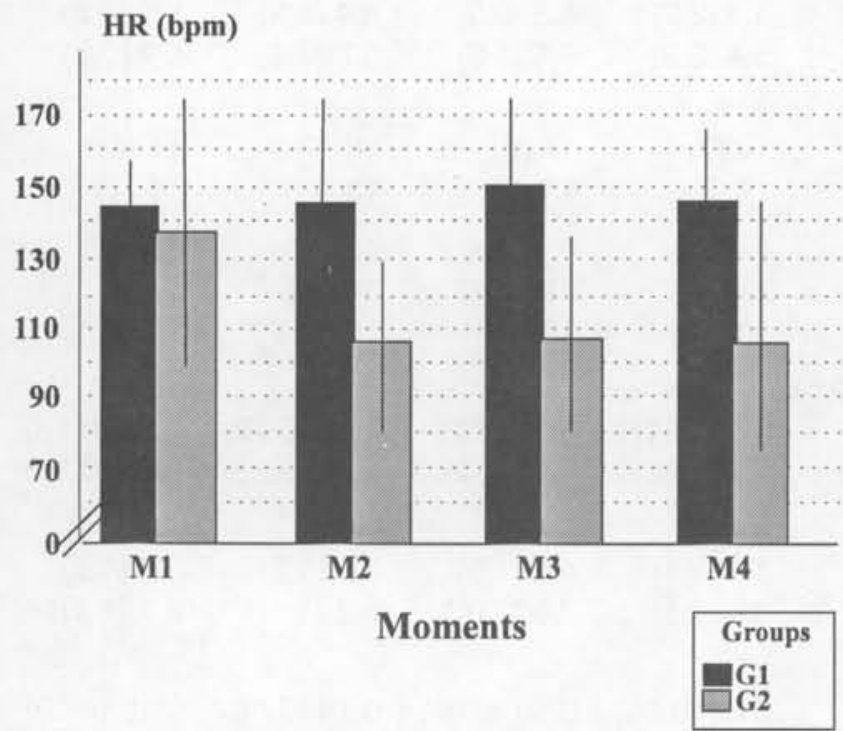

Figure 1 - Heart rate in G1 (SP) and G2 (fentanyl)

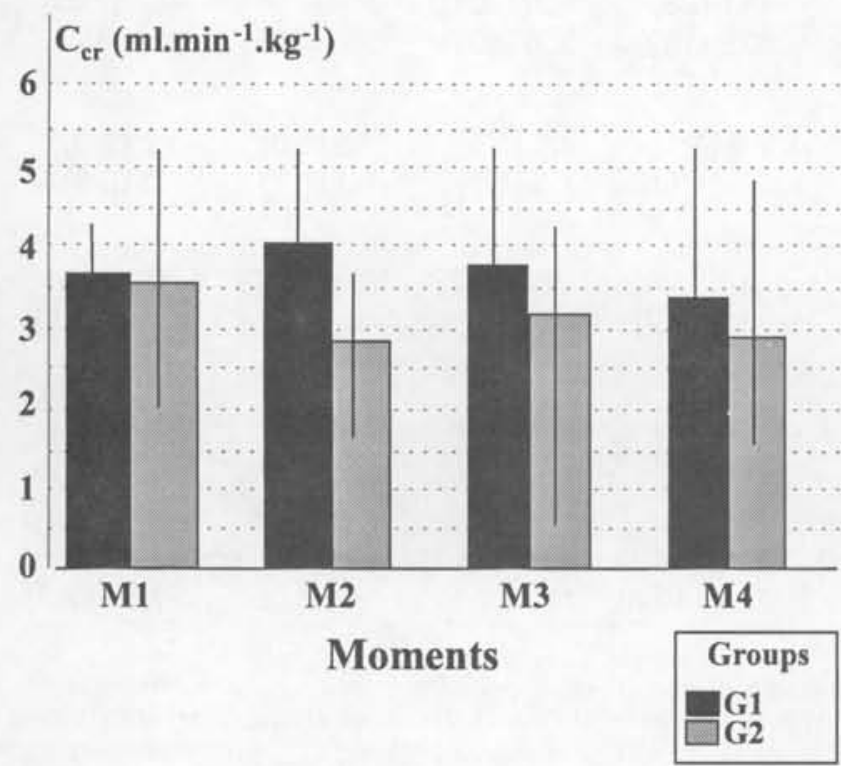

Figure 3 - Creatinine clearance in G1 (SP) and G2 (fentanyl)
Taneyama et al. ${ }^{23}$ in a denervation study performed in dogs, reported that the reduction of MAP produced by fentanyl may be mainly due to the reduction of sympathetic outflow. Flacke et al. ${ }^{17}$ demonstrated that fentanyl alone decreased plasma catecholamine levels, which might indicate lower sympathetic nerve activity. The decreased MAP in G2 may have caused lower glomerular capillary hydrostatic pressure and thus reducing $\mathrm{C}_{\mathrm{cr}}$, which is an estimation of glomerular filtration rate (GFR). GFR influences urine output more than any other one factor.

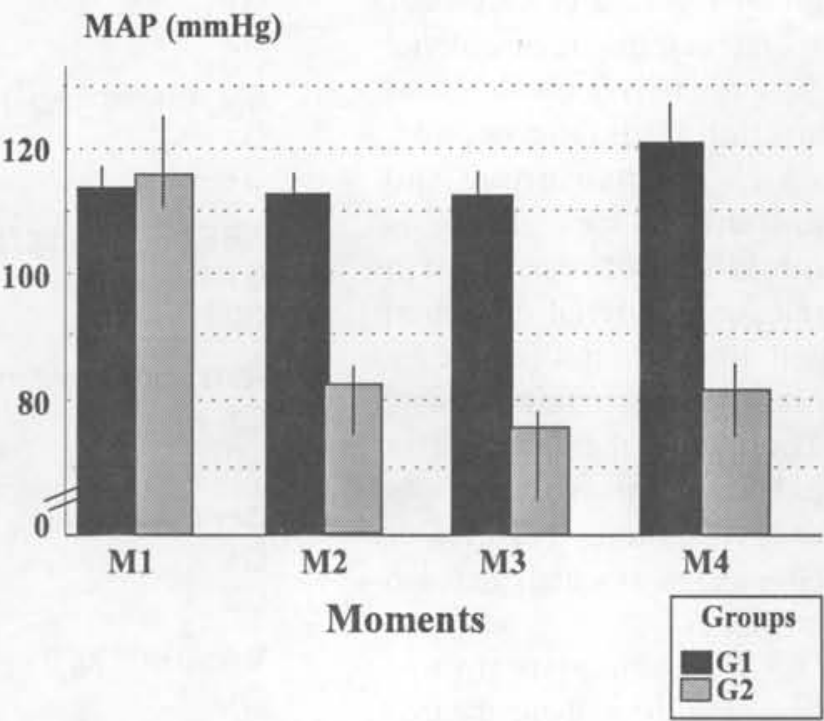

Figure 2 - Medium arterial pressure in G1 (SP) and G2 (fentanyl)

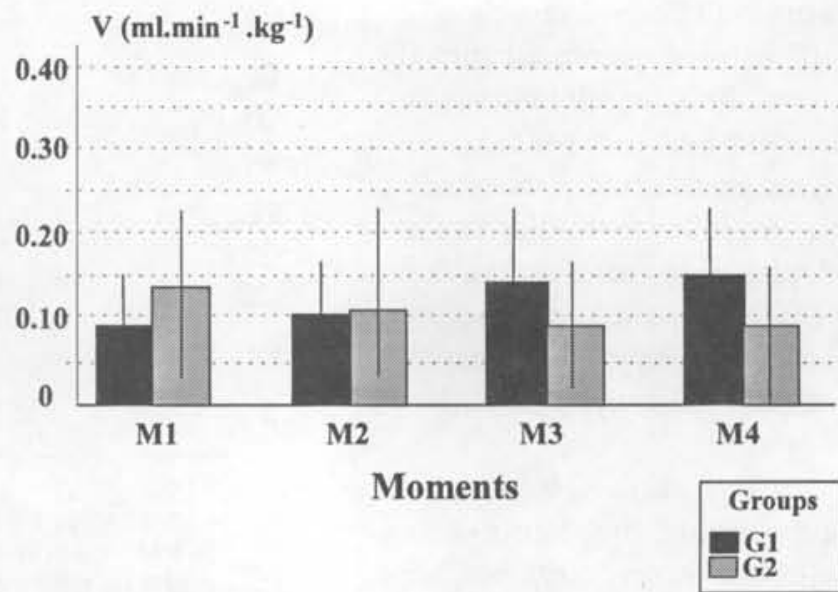

Figure 4 - Urinary output in G1 (SP) and G2 (fentanyl) 


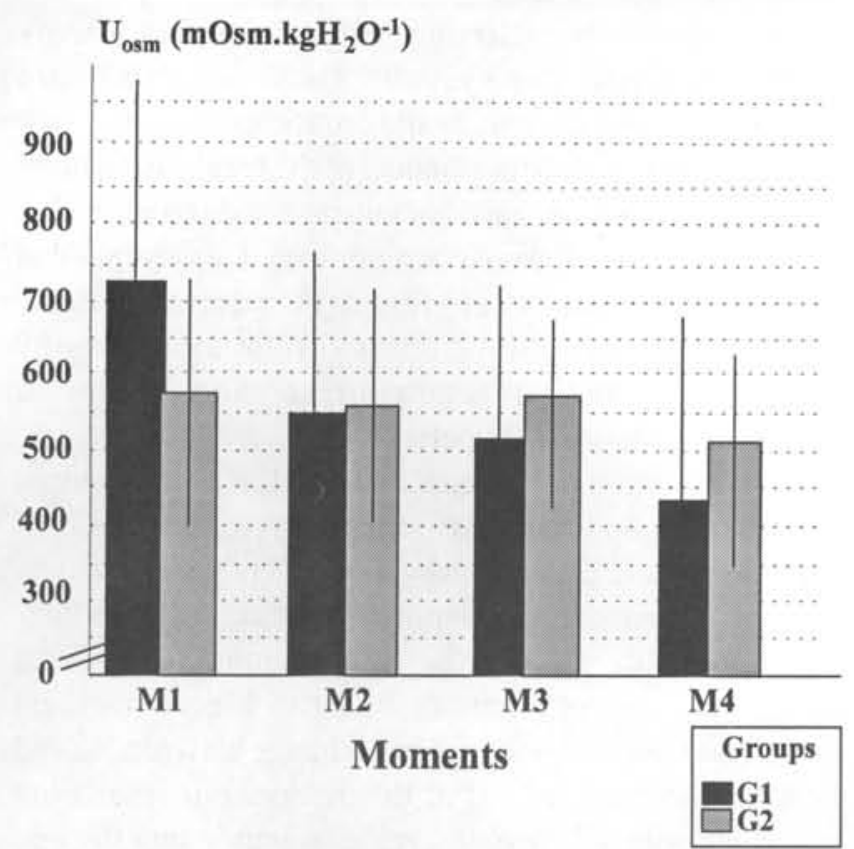

Figure 5 - Urinary osmolarity in G1 (SP) and G2 (fentanyl)

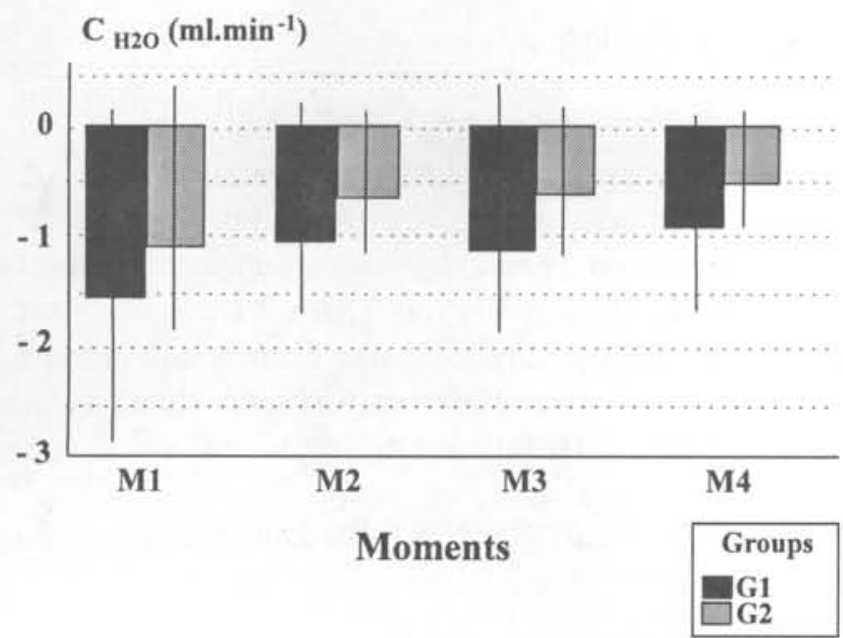

Figure 7 - Free water clearance in G1 (SP) and G2 (fentanyl)

There are two main mechanisms responsible for the preservation of renal perfusion in the presence of a decreased blood pressure. First, the normal kidney autoregulates its blood flow, keeping an almost constant $\mathrm{RBF}$ within a MAP range of $80-180 \mathrm{mmHg}$. The second possible mechanism is the intrarenal secretion of prostaglandins $\mathrm{PGE}_{2}$ and $\mathrm{PGI}_{2}$. Both are potent vasodilators. ${ }^{24}$

Our data suggest that these two responses may be preserved during high-dose fentanyl-induced hypotension. $\mathrm{C}_{\mathrm{PAH}}$ and RBF did not change and RVR was only slightly (and not significantly) reduced, despite a marked decrease

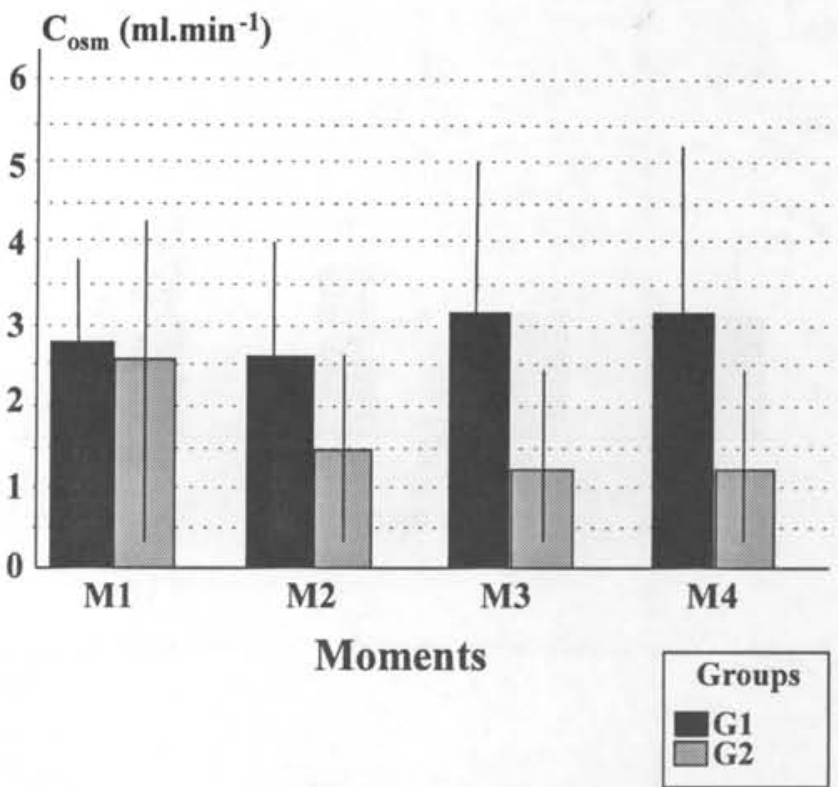

Figure 6 - Osmolar clearance in G1 (SP) and G2 (fentanyl)

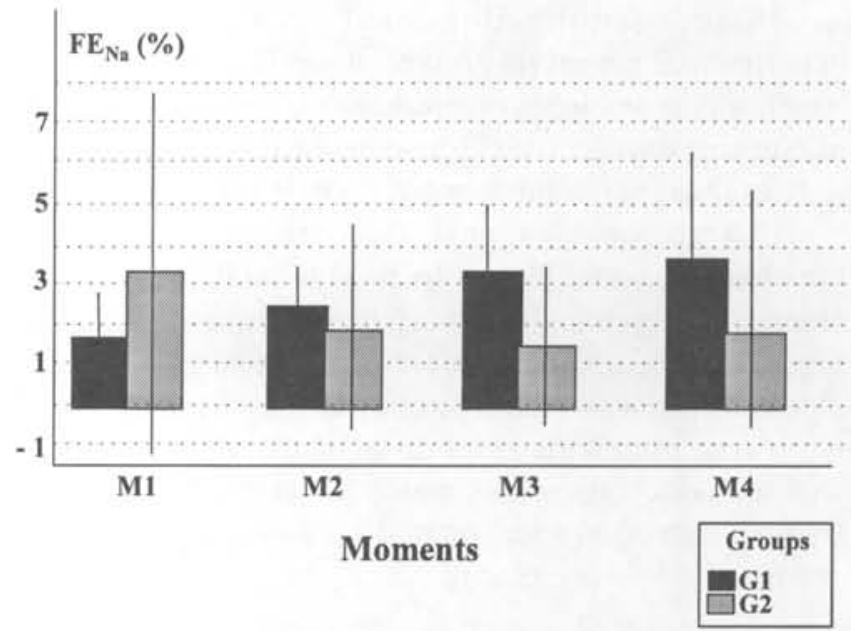

Figure 8 - Sodium fractional excreption in G1 (SP) and G2 (fentanyl)

in perfusion pressure. Thus, the significant decrease of $\mathrm{GFR}\left(\mathrm{C}_{\mathrm{cr}}\right)$ possibly was minimized.

Fentanyl, a $\mu$ opiate receptor agonist, diminishes V in the dog. ${ }^{1,2}$ This effect, common to most opiates, has been attributed to the stimulation of vasopressin (an antidiuretic hormone) release. ${ }^{25}$ More recent evidence suggests that this is not the decisive factor, although in this study mediated, may be a reduction in GFR. ${ }^{26,27}$

In our study, MAP and $\mathrm{C}_{\mathrm{cr}}$ decreased in $\mathrm{G} 2$, while $\mathrm{C}_{\mathrm{PAH}}$ and RBF did not. However, GRF begins to decrease at higher renal perfusion pressure than RBF. As diuresis is governed mainly by two physiological mechanisms - by 


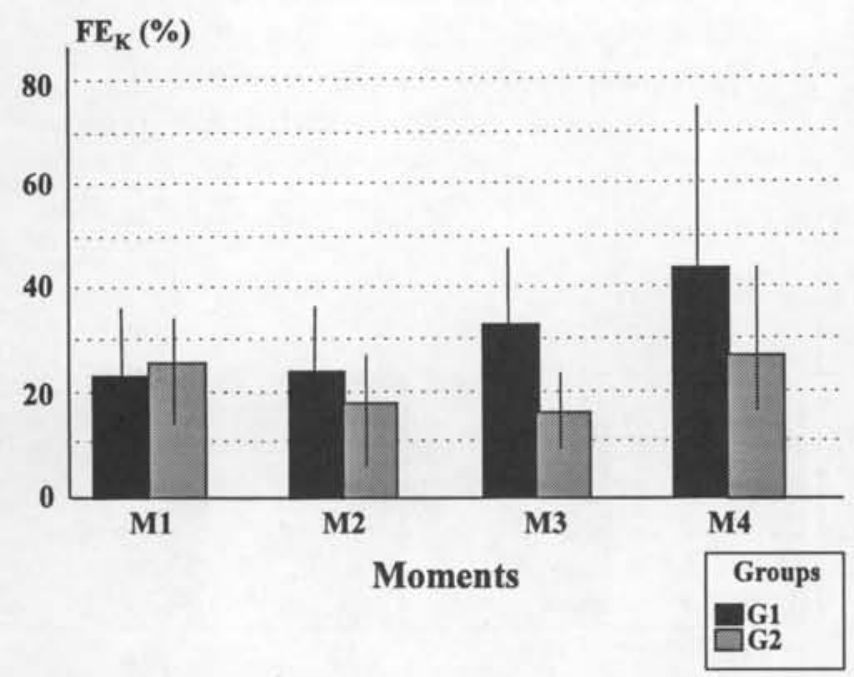

Figure 9 - Potassium fractional excreption in G1 (SP) and G2 (fentanyl)

regulation of the RBF and GFR $\left(\mathrm{C}_{\mathrm{cr}}\right)$, and by variation of tubular reabsorption - these alterations would already be contributing to reducing V (as observed in $\mathrm{G} 2$ ).

Since stabilization of $U_{\text {osm }}$ followed each experimental period (in control group $\mathrm{U}_{\text {osm }}$ decreased all time), it is possible that there was retention or water and also of solutes, because $\mathrm{C}_{\text {osm }}$ decreased after fentanyl. $\mathrm{C}_{\mathrm{H} 2 \mathrm{O}}$ did not change after the fentanyl dose (in G1, it increased).

These facts suggest aldosterone action. The hypotension would have activated the renin-angiotensinaldosterone system; the end product of renin release is the production of angiotensin II, which in turn stimulates aldosterone release. Aldosterone impacts on renal salt and water retention; it increases distal tubular reabsorption of sodium, which decreases water excretion. Thus, in our study, V decreased after fentanyl administration, and urine presented stable osmolarity.
Another factor affecting renin-angiotensin activity is the prostaglandin system. These materials are synthesized from fatty acids and are secreted by the renal medulla. Apart from being dilators of the renal vasculature, they produce renin release but enhance sodium excretion by the tubules. On the contrary, our data demonstrate that $\mathrm{FE}_{\mathrm{Na}}$ diminished after fentanyl administration. Prostaglandins can also be released from the kidney by angiotensin and norepinephrine and under a vasoconstrictive state (hypotensive). ${ }^{24}$

In contrast to what happened in $\mathrm{G} 1, \mathrm{Na}$ and $\mathrm{K}$ output decreased. Aldosterone normally enhances $\mathrm{Na}$ reabsorption and $\mathrm{K}$ secretion by the distal tubule. However, there is no mandatory coupling between these cellular mechanisms. In other words, the $\mathrm{Na}$ amount in the distal lumen tubule is not a limiting factor to $\mathrm{K}$ secretion, and there is no observed one-to-one exchange between $\mathrm{Na}$ and $\mathrm{K}$ at this nephron level. For this reason, our results are consistent with aldosterone having an important effect on Group 2.

\section{CONCLUSIONS}

In the population of dogs which received only SP, the observed behavior can be attributed to extracellular volume expansion. These animals were compared to others received high-dose fentanyl. There were significant decreases in RF, probably due to significant opioid-induced hemodynamic changes. However, we cannot eliminate the possibility of main action due to aldosterone.

ACKNOWLEDGEMENT: We thank Prof. Dr. Paulo Roberto Curi for statistical advice and analysis.

\section{RESUMO}

Objetivos: Estudamos os efeitos de alta dose de fentanil (F) em atributos de função renal (FR) do cão. Desenho: Anestesiamos com pentobarbital sódico (PS) 16 cães divididos aleatoriamente em 2 grupos: manutençăo com PS (G1) e PS com F (0,05 mg. $\mathrm{kg}^{-1}$ ) (G2). Intervenção: os cães foram ventilados artificialmente e tiveram cateterizadas as veias femorais esquerda e direita e a artéria femoral esquerda para infusão de drogas e coleta de dados hemodinâmicos e de sangue para dosagens laboratoriais. Coletou-se urina durante todo experimento. Mensuração: Determinaram-se os valores de atributos de FR.. Resultados: PS não mudou a FR e o comportamento de G1 deveu-se à expansão do volume extracelular. O F diminuíu significativamente freqüência cardiaca, pressão arterial média, "clearance" de creatinina, volume urinário, "clearance" osmolar e excreção fracionária de sódio e potássio. Conclusões: A diminuição da FR foi provavelmente devida às alteraçōes hemodinâmicas induzidas pelo $F$, não se descartando possível ação da aldosterona. 


\section{REFERENCES}

1. Bawd AV, Liu WS, Stanley TH, Bidwai V; Loeser EA, Shaw CL. The effects of large doses of fentanyl and fentanyl with nitrous oxide on renal function in the dog. Can Anesth Soc J 1976;23:296-302.

2. Hunter JM, Jones RS, Utting JE. Effect of anesthesia with nitrous oxide in oxygen and fentanyl on renal function in the artificially-ventilated dog. Br J Anesth 1980;52:343-48.

3. Kono K, Philbin DM, Coggins C H, Triantafillon A, Schneider RC. Renal function in cardiac patients during halothane on fentanyl anesthesia. Anesth Analg 1981;60:260-1.

4. Priano LL. Effects of high-dose fentanyl on renal haemodynamics in conscious dogs. Can Anesth Soc J 1983;30:10-8.

5. Conger JD, Burke TJ. Effects of anesthetic agents on autoregulation of renal hemodynamics in the rat and dog. Am J Physiol 1976;230:652-7.

6. Braz JRC, Curi PR, Vianna PTG, Castiglia YMM, Lemonica L. Efeitos do óxido nitroso em normóxia e hiperóxia sobre a função renal do cão. Rev Bras Anest 1985;35:19-25.

7. Smith $\mathrm{HW}$, Finkelstein N, Aluminosa L, Crawford B, Graber M. The renal clearance of substitute of hipuric acid derivatives and other aromatic acids in dogs and man. J Clin Invest $1945 ; 24: 388-404$.

8. Shoch HK, Camara AA. Endogenous creatinine clearance. Meth Med Res 1957;5:214-19.

9. Morrison DF. The multivariate analysis of variance. In: Multivariate statistical methods. New York: McGraw-Hill, 1967:159-99.

10. Singer JM Análise de curvas de crescimento, São Paulo, 1977. 112f. (Tese - Mestrado - Instituto de Matemática e Estatística - Universidade de São Paulo).

11. Kempthorne O. The design and analysis of experiments. New York: John Wiley, 1967:631.

12. Massone F. Anestesiologia veterinária. Farmacologia e Técnicas. Rio de Janeiro: Editora Guanabara S.A., 1988:229.

13. Barlow G, Knott DH. Hemodynamic alterations after 30 minutes of sodium pentobarbital anesthesia in dogs. Am J Physiol 1964;207:764-6.

14. Page $\mathrm{IH}, \mathrm{McCubbin} \mathrm{JW}$. Autonomic regulation of arterial pressure responses. Arch Int Pharmacodyn Thér 1965;157:152-65.

15. Manders WT, Vatner SF. Effects of sodium pentobarbital anesthesia on left ventricular function and distribution of cardiac output in dogs, with particular reference to the mechanism for tachycardia. Circ Res 1976;39:512-7.

16. Blake WA. Some effects of pentobarbital anesthesia on renal hemodynamics, water and electrolyte excretion in the dog. Am J Physiol 1957;191:393-8.

17. Flacke J W, Flacke WE, Bloor BC, Olewine BS. Effects of fentanyl, naloxone, and clonidine on hemodynamics and plasma catecholamine levels in dogs. Anesth Analg 1983;62:305-13.

18. Laubie M, Schmitt H, Canellas J, Roquebert J. Centrally mediated bradycardia and hypotension induced by narcotic analgesics: Dextromoramide and fentanyl. Eur J Pharmacol 1974;28:66-75.

19. Laubie M, Schmitt H, Drouillat M. Central sites and mechanisms of the hypotensive and bradycardic effects of the narcotic analgesic agent fentanyl. Arch Pharmacol 1977;296:255-61.

20. Couture P, Boudreault D, Girard D et al. Haemodynamic interaction of high-dose fentanyl and increasing doses of vecuronium in patients undergoing myocardial revascularization. Acta Anaesthesiol Scand 1996;40:32-8.

21. Rorie DK, Muldoon SM, Tyce GM. Effects of fentanyl on adrenergic function in canine coronary arteries. Anesth Analg 1981;60:21-7.

22. Vane LA, Braz JRC, Oliveira JSM et al. Efeitos do fentanil sobre a adrenalina e noradrenalina plasmáticas e do miocárdio. Estudo experimental no cão. Rev Paul Med 1987;105:25-31.

23. Taneyama C, Goto H, Kohno N, Benson KT, Sasao J, Arakawa $\mathrm{K}$. Effects of fentanyl, diazepam, and the combination of both on arterial baroreflex and sympathetic nerve activity in intact and barodenervated dogs. Anesth Analg 1993;77:44-8.

24. Brenner BM, Rector Jr FC. In: The Kidney. Philadelphia: W. B. Saunders Company, 1991:1368.

25. Firemark HM, Weitzman RE. Effects of b-endorphin, morphine and naloxone on arginine vasopressin secretion and the electroencephalogram. Neuroscience 1979;4:1895-902.

26. Huidobro-Toro JP, Huidobro F. Central effects of morphine, levorphanol, (-) methadone and the opioid - like peptides bendorphin and D-alanine ${ }_{2}$ - methionine enkephalinamide on urine volume outflow and electrolytes. J Pharmacol Exper Ther 1981;217:579-85.

27. Grell S, Dencker Christensen J, Fjalband B. Morphine antidiuresis in conscious rats. Contribution of vasopressin and blood pressure. Acta Pharmacol Toxicol 1985;56:38-43. 